\title{
Virus-specific proteins in cells infected with tomato black ring nepovirus: evidence for proteolytic processing in vivo
}

\author{
G. Demangeat, ${ }^{1}$ O. Hemmer, ${ }^{1}$ J. Reinbolt, ${ }^{2}$ M. A. Mayo $^{3}$ and C. Fritsch ${ }^{1 *}$ \\ ${ }^{1}$ Institut de Biologie Moléculaire des Plantes, 12 rue du Général Zimmer, 67000 Strasbourg, ${ }^{2}$ Institut de Biologie \\ Moléculaire et Cellulaire, 15 rue Descartes, 67000 Strasbourg, France and ${ }^{3}$ Scottish Crop Research Institute, Invergowrie, \\ Dundee DD2 5DA, U.K.
}

The synthesis of proteins encoded by the RNA of tomato black ring virus (TBRV) in vivo was studied in protoplasts by direct labelling with $\left[{ }^{35}\right.$ S]methionine, and in protoplasts and plants by immunoblotting experiments with specific antisera. Comparison of the proteins synthesized in infected and mock-inoculated protoplasts suggested that proteins of $M_{\mathrm{r}} 120 \mathrm{~K}, 90 \mathrm{~K}$, $80 \mathrm{~K}, 57 \mathrm{~K}$ and $46 \mathrm{~K}$ were virus-specific. The proteins derived from the RNA-1-encoded polyprotein detected by immunoblotting were a stable $120 \mathrm{~K}$ protein and, only in protoplasts, small amounts of a $90 \mathrm{~K}$ protein which contains the $C$-terminal part of the $120 \mathrm{~K}$ protein and the polymerase domain. The results suggest that the polymerase and the adjacent protease function in vivo largely or solely when combined in a $120 \mathrm{~K}$ protein. The proteins derived from the RNA-2-encoded poly- protein detected by immunoblotting were $59 \mathrm{~K}$ and $57 \mathrm{~K}$ proteins, which reacted with antiserum to TBRV particles, and a $46 \mathrm{~K}$ protein. In extracts of infected Nicotiana clevelandii and Chenopodium quinoa made soon after inoculation, the $59 \mathrm{~K}$ protein was more abundant than the $57 \mathrm{~K}$ protein; later samples contained similar quantities of each protein. The $57 \mathrm{~K}$ protein comigrated with protein extracted from virus particles. The results of amino acid sequencing suggested that the $57 \mathrm{~K}$ protein is derived from the $59 \mathrm{~K}$ protein by the loss of nine $\mathrm{C}$-terminal amino acids. Antiserum to a peptide adjacent to the $57 \mathrm{~K}$ protein in the $150 \mathrm{~K}$ polyprotein detected a $46 \mathrm{~K}$ protein in protoplasts and plant tissue. The results support the processing scheme for TBRV polyproteins proposed after analysis of the products of in vitro translation.

\section{Introduction}

Tomato black ring nepovirus (TBRV) has a bipartite genome: RNA-1 7359 nucleotides + poly(A)] encodes a polyprotein with an $M_{\mathrm{r}}$ of $250 \mathrm{~K}$ (Greif et al., 1988) and RNA-2 [4662 nucleotides + poly(A)] encodes a polypeptide of 150K (Meyer et al., 1986). When TBRV RNAs are translated in vitro, each polyprotein is cleaved by a proteolytic activity contained in the RNA-1-encoded $250 \mathrm{~K}$ polyprotein (Demangeat et al., 1990, 1991). All the proteins detected in vitro could be located within the polyproteins and a genetic organization was proposed (Demangeat et al., 1990, 1991) which resembled that predicted from the nucleotide sequences (Greif et al., 1988) (Fig. 1). Of the three proteins produced in vitro by cleavage of the $150 \mathrm{~K}$ polyprotein, the C-terminal protein corresponds to the viral coat protein. However, this protein migrates slightly more slowly than that extracted from purified virus particles and is called the $59 \mathrm{~K}$ protein (Demangeat et al., 1991); previous estimates of the $M_{\mathrm{r}}$ of TBRV coat protein (Randles et al., 1977), including the protein detected in earlier experiments on
TBRV-infected protoplasts (Fritsch et al., 1978), were 57K. Another unusual feature found by Demangeat $e t a l$. (1990) was that although the $120 \mathrm{~K}$ cleavage product of the $250 \mathrm{~K}$ polyprotein contains both the region thought to be a protease and the region thought to be the virus polymerase, it is never cleaved into these products in vitro.

These results suggested either that the cleavages observed in vitro are incomplete or that the cleavage of the polyproteins in vivo differs from that observed in vitro. This paper describes experiments designed to determine the occurrence, in TBRV-infected protoplasts and in leaf tissues, of cleavage of the $250 \mathrm{~K}$ polyprotein to yield the $120 \mathrm{~K}$ and $90 \mathrm{~K}$ proteins, and cleavage of the $150 \mathrm{~K}$ polyprotein to yield the coat and $46 \mathrm{~K}$ proteins.

\section{Methods}

\footnotetext{
Virus purification. Particles of isolate S of TBRV (Fritsch et al., 1984) were purified from systemically infected leaves from Nicotiana clevelandii plants as described by Fritsch et al. (1978). Some virus
} 


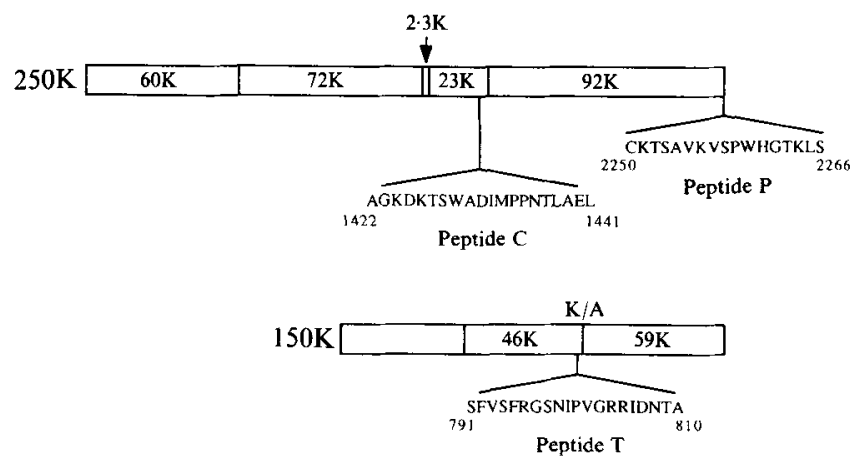

Fig. 1. Diagram of the polyprotein translation products of TBRV RNA-1 and RNA-2 showing their positions in the polyproteins and the sequences of the synthetic peptides $T, P$ and $C$. Polyproteins are represented by boxes which contain the sizes of the putative products of proteolytic maturation. Numbers indicate the positions of the terminal amino acids of each peptide with reference to the sequence of Greif et al. (1988) after correction to add three extra A residues (see Methods).

preparations were further purified by centrifugation to equilibrium in CsCl solutions (Demangeat et al., 1990).

Preparation, inoculation and culture of protoplasts. Protoplasts were isolated as described by Kubo et al. (1975) from leaves from $N$. tabacum $\mathrm{cv}$. Xanthi plants and inoculated following the procedure of Barker \& Harrison (1977). The protoplasts were kept at $20^{\circ} \mathrm{C}$ under constant illumination at 3000 lux. After culture for $48 \mathrm{~h}$, protoplast viability, assessed by the ability to take up and hydrolyse fluorescein diacetate, was $>70 \%$; more than $70 \%$ of inoculated protoplasts were deemed to be infected because they could be stained with fluorescein isothiocyanate-conjugated antibody to TBRV particles

Analysis of protein synthesis. At about $23 \mathrm{~h}$ post-infection (p.i.), $40 \mu \mathrm{Ci}$ $(1.48 \mathrm{MBq})$ of $\left[{ }^{35} \mathrm{~S}\right]$ methionine $(1000 \mathrm{Ci} / \mathrm{mmol} ;$ Amersham) was added to samples of $2 \times 10^{5}$ protoplasts in $0.5 \mathrm{ml}$ of culture medium. After labelling, protoplasts were collected by centrifugation and resuspended in $100 \mu \mathrm{l}$ of buffer containing $120 \mathrm{~mm}$-Tris- $\mathrm{HCl} \mathrm{pH} 8,5 \%$ SDS, $150 \mathrm{mM}$-DTT and $20 \%$ glycerol. The samples were then heated at $100{ }^{\circ} \mathrm{C}$ for $3 \mathrm{~min}$ and analysed by SDS-PAGE and autoradiography (Fritsch et al., 1978).

Infection of whole plants and subcellular fractionation. Chenopodium quinoa or $N$. clevelandii plants were inoculated with an extract of TBRV-infected leaves and grown at a constant $22^{\circ} \mathrm{C}$. Leaves were collected at various times after inoculation and subcellular fractions were prepared essentially as described by Godefroy-Colburn $e t$ al. (1986). Leaf samples $(2 \mathrm{~g})$ were cut into small pieces in $2 \mathrm{ml}$ of ice-cold buffer $\left(100 \mathrm{~mm}\right.$-Tris- $\mathrm{HCl} \mathrm{pH} 7.6,10 \mathrm{~mm}-\mathrm{KCl}, 5 \mathrm{~mm}-\mathrm{MgCl}_{2}, 10 \%$ glycerol, $10 \mathrm{~mm}$-2-mercaptoethanol) and the mixture was filtered by centrifugation at $1000 \mathrm{~g}$ for $5 \mathrm{~min}$ through a nylon cloth. The supernatant fraction was centrifuged at $30000 \mathrm{~g}$ for $30 \mathrm{~min}$ to obtain pellet and soluble fractions. Samples of these fractions were mixed with two volumes of $85 \mathrm{~mm}$-Tris- $\mathrm{HCl} \mathrm{pH} 6.8,6 \%$ SDS, 9\% 2-mercaptoethanol, 9 M-urea, heated and analysed by SDS-PAGE.

Peptides and antisera. Peptide T (Fig. 1) was synthesized to correspond in sequence to amino acids 791 to 810 of the RNA-2encoded $150 \mathrm{~K}$ polyprotein (Demangeat et al., 1991). Synthetic peptides $C$ and $P$ (Fig. 1) correspond to amino acids 1421 to 1440 (C) and 2249 to 2265 (P) of the RNA-1-encoded $250 \mathrm{~K}$ polyprotein (Greif et al., 1988). This sequence lacks three nucleotides (insertions of $A$ residues at positions 3244, 3279 and 3294 in the published sequence) and the true amino acid coordinates for the peptides, as shown in Fig. 1, are one greater than those given by Greif et al. (1988). Antisera were raised by injecting rabbits with ovalbumin-conjugated peptide as described by Demangeat $e t$ al. (1990). The antisera reacted readily, when diluted about 1:20000, with 0.5 $\mathrm{gg}$ of homologous peptide in ELISA.

Analysis of viral proteins by immunoblotting. After separation by SDSPAGE the proteins were electroblotted to a nitrocellulose sheet (Schieicher \& Schuell) for $90 \mathrm{~min}$ at $400 \mathrm{~mA}$ essentially as described by Towbin et al. (1979). Blots were then reacted with a $1: 1500$ dilution of antiserum followed by a 1:2000 dilution of alkaline phosphataseconjugated goat anti-rabbit IgG (Niesbach-Klösgen et al., 1990). The specificity of the reactions was assessed by mixing the antiserum with an excess of the specific immunogen prior to the reaction and observing competitive inhibition.

Determination of $\mathrm{N}$ - and $\mathrm{C}$-terminal amino acid of the coat protein. To determine the $\mathrm{N}$ terminus, $2 \mu \mathrm{g}$ of $\mathrm{CsCl}$-purified virus particles in $60 \mathrm{mM}$-sodium phosphate buffer $\mathrm{pH} 6.8$ was dissociated by heating at $100{ }^{\circ} \mathrm{C}$ for $3 \mathrm{~min}$ in $80 \mathrm{~mm}$-Tris- $\mathrm{HCl} \mathrm{pH} 6.8,5 \% \mathrm{SDS}$ and $12 \%$ 2-mercaptoethanol. After SDS-PAGE the coat protein was electroblotted to an Immobilon PVDF membrane as described by the manufacturer (Millipore) using a semi-dry blotter. The piece of membrane corresponding in position to the coat protein was then directly subjected to automated Edman degradation using an Applied Biosystems $470 \mathrm{~A}$ protein sequencer equipped with a PTH 120A analyser (Hewick et al., 1981).

To determine the $\mathrm{C}$ terminus, the region of the gel containing the coat protein was cut out and the coat protein was electroeluted in a dialysis bag overnight at $180 \mathrm{~V}$ in $25 \mathrm{~mm}$-Tris, $192 \mathrm{mM}$-glycine, $0.1 \%$ SDS buffer and concentrated to approximately $500 \mu \mathrm{g} / \mathrm{ml}$ by ultrafiltration in a Centricon 30 microconcentrator. Protein was digested with carboxypeptidase $A$ (Sigma) at an enzyme:protein ratio of $1: 30$ in $0.1 \mathrm{M}-N$-methylmorpholine $\mathrm{pH} 8$ for $2 \mathrm{~h}$ at $37^{\circ} \mathrm{C}$. The amino acid content was analysed by using a 420 A-130 A derivatization and analysis system (Applied Biosystems).

\section{Results}

\section{Detection of infection-specific polypeptides by ${ }^{35}$ S]methionine labelling}

In preliminary experiments, protoplasts were inoculated with TBRV, or mock-inoculated, and cultured in the presence of $\left[{ }^{35} \mathrm{~S}\right] \mathrm{methionine.} \mathrm{After} \mathrm{electrophoresis} \mathrm{some}$ polypeptides were detected in samples of infected but not mock-inoculated protoplasts (Fig. $2 a$ ); these had $M_{\mathrm{r}} \mathrm{s}$ of $120 \mathrm{~K}, 90 \mathrm{~K}, 80 \mathrm{~K}, 57 \mathrm{~K}$ and $46 \mathrm{~K}$. In protoplasts sampled $12 \mathrm{~h}$ (Fig. $2 b$ ), rather than $6 \mathrm{~h}$ (Fig. $2 a$ ), after adding methionine, the $120 \mathrm{~K}$ and $57 \mathrm{~K}$ polypeptides were evident, the $90 \mathrm{~K}$ polypeptide was obscured by a similarly sized polypeptide in protein from mock-inoculated protoplasts, and the $80 \mathrm{~K}$ and $46 \mathrm{~K}$ polypeptides were not detectable. In further experiments, antisera specific to virus genome-encoded proteins were used to detect viral proteins.

\section{Serological detection of the $120 \mathrm{~K}$ polypeptide}

Protein extracted from infected protoplasts and from infected $C$. quinoa tissue contained a $120 \mathrm{~K}$ polypeptide 
(a)

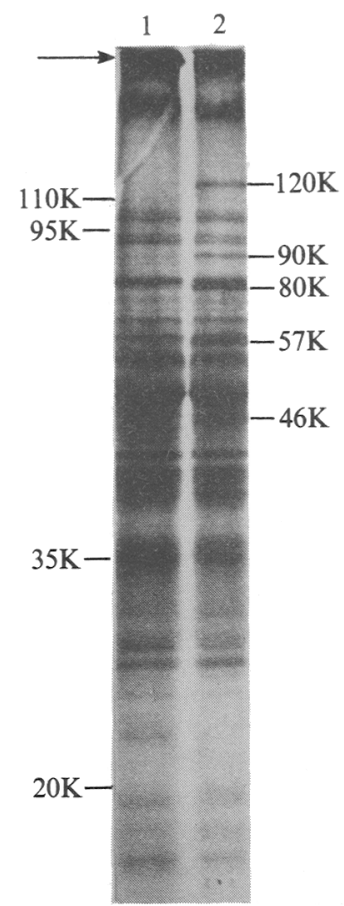

(b)

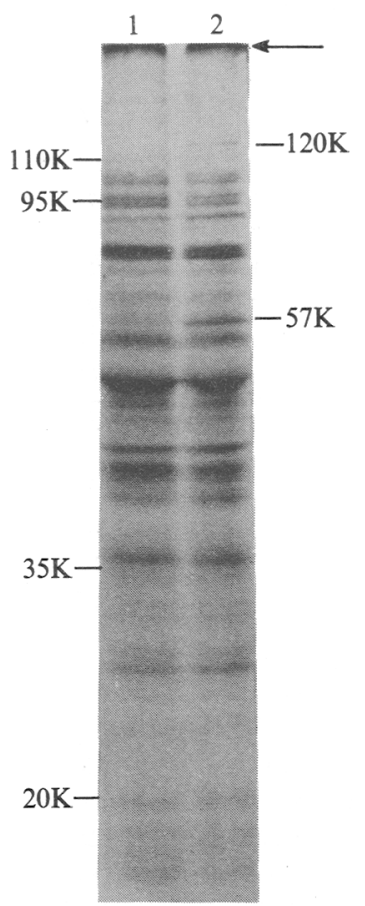

(a)

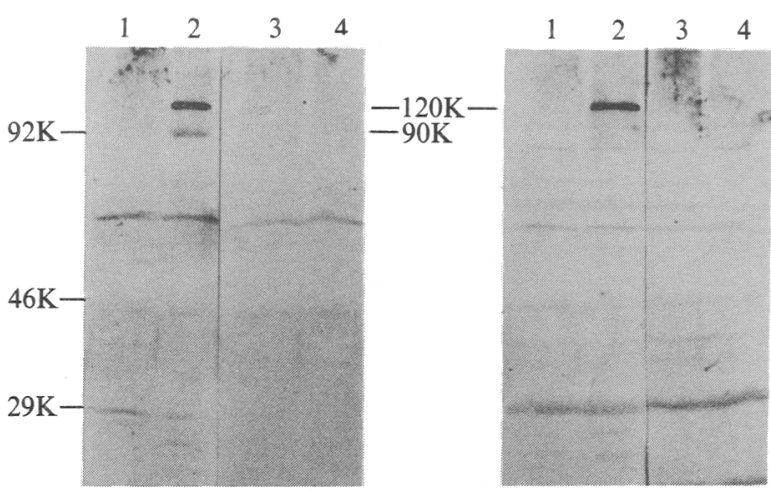

Fig. 3. Immunoblot detection of infection-specific polypeptides in protoplasts by using anti-peptide $\mathrm{P}(a)$ and anti-peptide $\mathrm{C}$ sera $(b)$. Protein was extracted from $2 \times 10^{4}$ mock-inoculated (lanes 1) or TBRV-infected (lanes 2) protoplasts. Lanes 3 and 4 contain samples as for lanes 1 or 2 but were subjected to competitive inhibition with homologous peptide. Numbers to the left indicate the positions and sizes of $M_{\mathrm{r}}$ markers (phosphorylase B, ovalbumin and carbonic anhydrase). Numbers in the centre indicate the $120 \mathrm{~K}$ and $90 \mathrm{~K}$ TBRVspecific proteins.

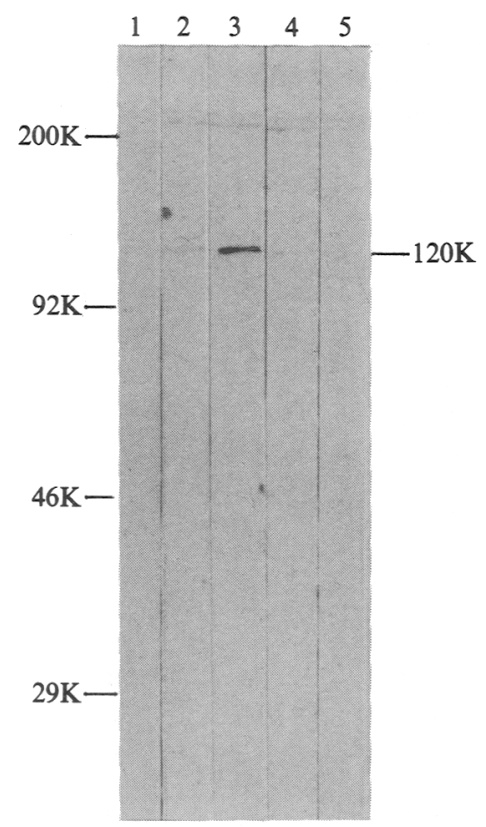

Fig. 2. Autoradiograph showing the detection of infection-specific [ ${ }^{35}$ S]methionine-labelled proteins in protoplasts. Protoplasts were cultured with methionine from $23 \mathrm{~h}$ p.i. until $29 \mathrm{~h}$ p.i. (a) or $35 \mathrm{~h}$ p.i. (b). Protein from $5 \times 10^{4}$ protoplasts was analysed in different $10 \%$ acrylamide gels ( $a$ or $b$ ). Numbers to the left of each autoradiograph indicate the positions of co-electrophoresed translation products of brome mosaic virus RNA (Symons, 1985), numbers to the right indicate the proteins present in infected protoplasts (lanes 2) but not in mock-inoculated protoplasts (lanes 1). The arrows indicate the tops of the gels.

which reacted in immunoblots with anti-peptide $P$ and anti-peptide $\mathrm{C}$ sera (Fig. 3). A small amount of a polypeptide of $90 \mathrm{~K}$ was also detected with anti-peptide $P$ serum, but not with anti-peptide $C$ serum. The polypeptides were absent from protein from mock-inoculated protoplasts and the reaction between the $120 \mathrm{~K}$ polypeptide and each antiserum was inhibited when peptide $C$ or peptide $\mathbf{P}$ was added to the respective antiserum during incubation with the blots (Fig. 3). Therefore the $90 \mathrm{~K}$ protein corresponds to the C-terminal of the $120 \mathrm{~K}$ protein obtained by in vitro translation of TBRV RNA (Demangeat et al., 1990). A $120 \mathrm{~K}$ polypeptide, but not a $90 \mathrm{~K}$ polypeptide, was also specifically detected in protein from infected C. quinoa tissue. To determine the kinetics of the appearance of the $120 \mathrm{~K}$ protein and its distribution among subcellular fractions, $C$. quinoa tissue was taken at intervals after inoculation and fractionated prior to preparing protein samples. The $120 \mathrm{~K}$ polypeptide was readily detected with anti-peptide $P$ serum in the soluble fraction of samples taken 5 days p.i. (Fig. 4, lane 3). Small amounts were present in this fraction 3 days p.i. (Fig. 4, lane 2), but none was detected in either 


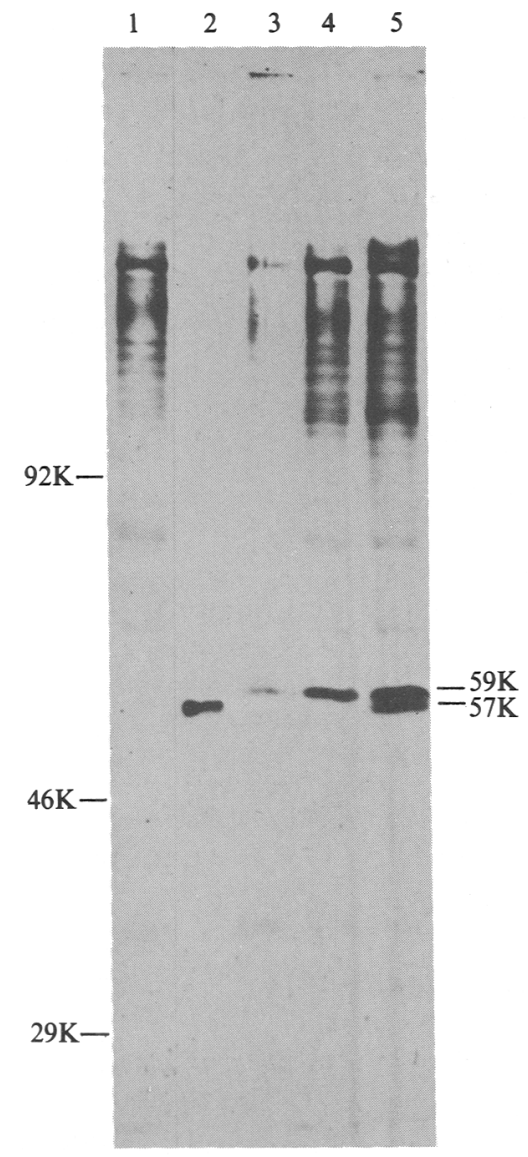

Fig. 5. Immunoblot detection of TBRV coat protein in infected $N$. clevelandii leaves. Protein was extracted from the soluble fraction of $2 \mathrm{mg}$ (fresh weight) of $N$. clevelandii leaves sampled at various times after inoculation. Lane 1, healthy leaf tissue; lane 2, protein from purified virus particles; lane 3 , infected leaves 3 days p.i.; lane 4 , infected leaves 5 days p.i.; lane 5 , infected leaves 11 days p.i. Numbers to the left indicate marker proteins as in Fig. 3. Numbers to the right indicate the immunoreactive $59 \mathrm{~K}$ and $57 \mathrm{~K}$ proteins.

sedimentable fraction (data not shown) at any time after inoculation. Essentially similar results were obtained when using anti-peptide $C$ serum.

\section{Serological detection of coat protein}

Coat protein is readily detected in infected protoplasts or infected leaves by a variety of serological methods. When protein was extracted from $N$. clevelandii leaves at various times and immunoblotted with antiserum to virus particles, several polypeptides were detected (Fig. 5). Those of $59 \mathrm{~K}$ and $57 \mathrm{~K}$ were not present in healthy tissue (Fig. 5, lane 1); the 57K polypeptide comigrated with protein extracted from purified virus particles (Fig. 5 , lane 2). In samples extracted from leaves 3 days or 5 days p.i. (Fig. 5 , lanes 3 and 4 ), the $59 \mathrm{~K}$ polypeptide

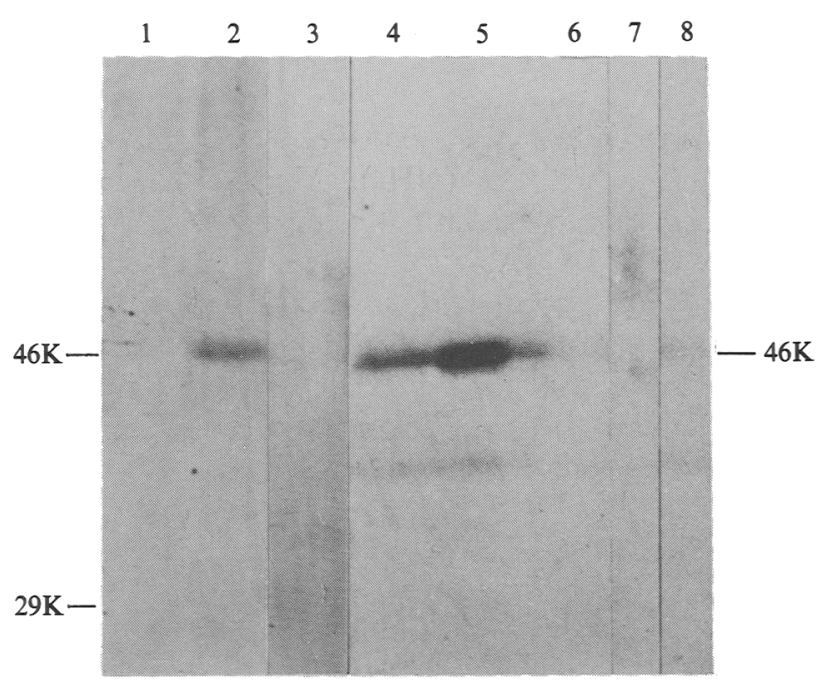

Fig. 6. Immunoblot detection of infection-specific polypeptides with anti-peptide $T$ serum. Samples were extracted from protoplasts $48 \mathrm{~h}$ p.i. or from the $30000 \mathrm{~g}$ pelleted fraction of $2 \mathrm{mg}$ (fresh weight) of C. quinoa leaves. Lane 1, mock-inoculated protoplasts; lane 2, TBRV-infected protoplasts; lane 3 , as in lane 2 but after competitive inhibition with peptide $T$; lane 4 , infected leaves 3 days p.i.; lane 5 , infected leaves 5 days p.i.; lane 6 , infected leaves 11 days p.i.; lane 7 , leaves from healthy plants; lane 8 , as in lane 5 but after competitive inhibition with peptide T. Numbers to the left indicate markers as in Fig. 3. Number to the right indicates the infection-specific $46 \mathrm{~K}$ protein.

was predominant, but later samples contained the $57 \mathrm{~K}$ and $59 \mathrm{~K}$ polypeptides in approximately equal amounts (Fig. 5, lane 5). Similar results were obtained with leaves from TBRV-infected $C$. quinoa plants.

\section{Serological detection of $46 \mathrm{~K}$ protein}

Immunoblots of protein from TBRV-infected protoplasts reacted with anti-peptide $T$ serum detected a single $46 \mathrm{~K}$ polypeptide (Fig. 6, lane 2); none was detected in mock-inoculated protoplasts (Fig. 6, lane 1) and the reaction was abolished by the addition of peptide T during the incubation with the antiserum (Fig. 6, lane 3). Similar results were obtained with protein from inoculated leaves from C. quinoa plants. Fractionation of the tissue followed by immunoblotting showed that all the reactive $46 \mathrm{~K}$ polypeptide sedimented at $30000 \mathrm{~g}$ or less. Approximately equal amounts were detected in the crude material pelleted at $1000 \mathrm{~g}$ and in the fraction pelleted at $30000 \mathrm{~g}$. The maximum amount of $46 \mathrm{~K}$ was detected 5 days p.i. (Fig. 6, compare lane 5 with lanes 4 and 6). In parallel samples analysed by immunoblotting with antiserum to virus particles, the amount of $57 \mathrm{~K}$ coat protein detected was much greater 11 days p.i. than 5 days p.i. 


\section{Determination of the $N$ and $C$ termini of the $57 K$ coat protein}

The sequence deduced for the $10 \mathrm{~N}$-terminal residues of the particle protein was $\left(\mathrm{NH}_{2}\right) \mathrm{A}-\mathrm{G}-\mathrm{G}-\mathrm{S}-\mathrm{Y}-\mathrm{A}-\mathrm{F}-\mathrm{G}-\mathrm{E}-\mathrm{T}$. The unambiguous $\mathrm{C}$-terminal sequence of the particle protein was $\mathrm{A}-\mathrm{T}-\mathrm{V}(\mathrm{COOH})$. Therefore the sequence of this protein is between residues 838 and 1348 of the $150 \mathrm{~K}$ polyprotein sequence (of 1357 amino acids) described by Meyer et al. (1986) and its calculated $M_{\mathrm{r}}$ is 55888 . However, for consistency with previously published work we will continue to designate this protein as $57 \mathrm{~K}$.

\section{Discussion}

The results show that the proteolytic cleavages of the polyproteins encoded by TBRV RNAs observed in vitro (Demangeat et al., 1990, 1991) are the same as, or very similar to, those which occur in vivo. The RNA-1encoded $250 \mathrm{~K}$ polypeptide yields a $120 \mathrm{~K}$ protein, which contains polymerase and protease domains (Greif et al., 1988 ), and the RNA-2-encoded $150 \mathrm{~K}$ polyprotein yields coat protein and a $46 \mathrm{~K}$ protein. However, we were unable to detect a protein corresponding to the $\mathrm{N}$-terminal portion of the $150 \mathrm{~K}$ polyprotein in immunoblotting experiments with an antiserum to a synthetic peptide from this region of the polyprotein, but this antiserum did not detect $150 \mathrm{~K}$ polypeptide in in vitro translation products and therefore may not have been very active.

Cleavage of the $120 \mathrm{~K}$ protein to give a $90 \mathrm{~K}$ product was observed only in protoplasts and then at a relatively low level. Although we cannot exclude the possibility that the $90 \mathrm{~K}$ protein is unstable and/or barely detectable, the simplest interpretation of this result is that this cleavage is uncommon and not related to an important viral function. It is thought that the protease domain in the $120 \mathrm{~K}$ protein is responsible for cleaving the polyproteins and, assuming that the proteins observed are significant functional species and not inactive byproducts, the results suggest that the protease can function while joined to a functional polymerase. During the processing of the polyprotein of poliovirus it is known that the $3 \mathrm{CD}$ protease-polymerase efficiently cleaves the $\mathrm{P} 1$ precursor to release capsid protein (Jore et al., 1988; Ypma-Wong et al., 1988).

The results with TBRV-infected cells resemble those obtained with cells infected with cowpea mosaic virus (CPMV). The polymerase and protease domains in the polypeptides encoded by CPMV B RNA (analogous to TBRV RNA-1) are also found in vivo in a single protein of $110 \mathrm{~K}$ (Dorssers et al., 1984). However, in vitro translation products of CPMV RNA include the separate constituent $87 \mathrm{~K}$ and $24 \mathrm{~K}$ proteins as well as the intact 110K species (Goldbach \& Rezelman, 1983). Although the 120K TBRV protein resembles the CPMV $110 \mathrm{~K}$ protein functionally, it is not found in association with membranes (as is the $110 \mathrm{~K}$ protein) but remains in the soluble fraction when centrifuged at $30000 \mathrm{~g}$. This may reflect differences in the mode of action of the two proteins or it may indicate that structures associated with TBRV replication are unstable during the fractionation procedures used.

In vitro translation of TBRV RNA yields a 59K product which contains the coat protein but migrates slightly more slowly than protein extracted from virus particles (Demangeat et al., 1991). The results presented in this paper show that a similar $59 \mathrm{~K}$ product is synthesized in infected leaves soon after inoculation, but that a $57 \mathrm{~K}$ product which comigrates with particle protein appears at later times after inoculation. When virus preparations were examined during purification, the particle protein fraction from partially purified virus contained both a $57 \mathrm{~K}$ and a $59 \mathrm{~K}$ protein, whereas that from highly purified virus contained only the $57 \mathrm{~K}$ protein. Previously reported estimates of the $M_{\mathrm{r}}$ of TBRV coat protein were probably made using such highly purified material.

An explanation for the appearance of two species of coat protein was obtained from the determination of the terminal amino acid sequences of the $57 \mathrm{~K}$ coat protein. The $\mathrm{N}$-terminal sequence corresponds to a protein commencing at amino acid 838 (as described by Demangeat et al., 1990) and the C-terminal sequence corresponds to a sequence that ends at amino acid 1348, nine amino acids upstream of the end of the $150 \mathrm{~K}$ polyprotein. Thus the $59 \mathrm{~K}$ protein may contain the sequence between amino acid 838 and the end of the $150 \mathrm{~K}$ polyprotein, and the $57 \mathrm{~K}$ protein may arise from it by the loss of the C-terminal amino acids. It is known that proteases can remove amino acids from the $\mathrm{C}$ termini of the coat proteins of tobacco mosaic virus (Harris \& Knight, 1952), potato virus X (Koenig et al., 1978) and potyviruses (Shukla et al., 1988). Presumably, as with these viruses, the C-terminal amino acids of TBRV coat protein protrude from the virus particle surface and can be removed without disrupting the virion. This exposed detachable fragment may play a significant role in TBRV biology as, for example, does the protruding $\mathrm{N}$-terminal fragment of potyvirus coat proteins in their transmission by aphids (Atreya et al., 1990). The C-terminal sequence of the $57 \mathrm{~K}$ protein (PLTIPATV) is very similar to that of the $150 \mathrm{~K}$ polyprotein of grapevine chrome mosaic nepovirus (GCMV) (PLTIPS; Brault et al., 1989). Perhaps GCMV, which is related serologically to TBRV, differs from it in a property mediated by the protruding $\mathrm{C}$ terminus, 
perhaps in vector specificity; however, the vector of GCMV is not known.

Some sequence homologies were detected between part of the TBRV $46 \mathrm{~K}$ protein and putative movement proteins of other viruses (Meyer et al., 1986); the analogous $48 \mathrm{~K}$ protein in the polyprotein encoded by CPMV M RNA plays a role in virus movement (Wellink \& van Kammen, 1989). The TBRV 46K protein resembles the CPMV 48K protein in that both are found in association with membranous material. However, the $48 \mathrm{~K}$ protein is found in the culture medium whereas the $46 \mathrm{~K}$ protein is not. The $46 \mathrm{~K}$ protein decreases in abundance later than 5 days after inoculation and is presumably either degraded or sequestered in an unextractable form.

In summary, the production of TBRV-encoded proteins in infected protoplasts and plants has confirmed the model of genome expression derived from the products of in vitro translation. Moreover, the similarity of the expression of the TBRV genome to that of the CPMV genome reinforces the similarities between nepoviruses and comoviruses deduced from the results of nucleotide sequencing studies (Wellink \& van Kammen, 1988). Functions have been assigned to the TBRV proteins by analogy, sometimes at third hand, with proteins of other viruses, but none has yet been assigned experimentally except for that of the coat protein. Moreover, even with this well understood protein the results shown in this paper suggest that there may be unsuspected subtleties in the way in which it functions.

We thank C. Hubert and P. Michler for photographic work. This work was supported in part by a Collaborative Research Grant from NATO.

\section{References}

Atreya, C. D., Raccah, B. \& Pirone, T. P. (1990). A point mutation in the coat protein abolishes aphid-transmissibility of a potyvirus. Virology 178, 161-165.

BARKER, H. \& HARRISON, B. D. (1977). Infection of tobacco mesophyll protoplasts with raspberry ringspot virus alone and together with tobacco rattle virus. Journal of General Virology 35, 125-133.

Brault, V., Hibrand, L., Candresse, T., Le Gall, O. \& Dunez, J. (1989). Nucleotide sequence and genetic organization of Hungarian grapevine chrome mosaic nepovirus RNA2. Nucleic Acids Research 17, 7809-7819.

Demangeat, G., Greif, C., Hemmer, O. \& Fritsch, C. (1990), Analysis of the in vitro cleavage products of the tomato black ring virus RNA-1-encoded $250 \mathrm{~K}$ polyprotein. Journal of General Virology 71, 1649-1654.

Demangeat, G., Hemmer, O., Fritsch, C., Le Gall, O. \& Candresse, T. (1991). In vitro processing of the RNA-2-encoded polyprotein of two nepoviruses: tomato black ring virus and grapevine chrome mosaic virus. Journal of General Virology 72, 247-252.

DORSSERS, L., VAN DER KROL, S., VAN DER MEER, J., VAN KAMMEN, A.
\& ZABel, P. (1984). Purification of cowpea mosaic virus RNA replication complex: identification of a virus-encoded 110000 dalton polypeptide responsible for RNA chain elongation. Proceedings of the National Academy of Sciences, U.S.A. 81, 1951-1955.

Fritsch, C., MaYo, M. A. \& MURANT, A. F. (1978). Translation of the satellite RNA of tomato black ring virus in vitro and in tobacco protoplasts. Journal of General Virology 40, 587-593.

Fritsch, C., Koenig, I., Murant, A. F., Raschiké, J. H. \& Mayo, M. A. (1984). Comparisons among satellite RNA species from five isolates of tomato black ring virus and one isolate of myrobalan latent ringspot virus. Journal of General Virology 65, 289-294.

Godefroy-ColbuRn, T., GageY, M.-J., BerNa, A. \& Stussi-Garaud, C. (1986). A non-structural protein of alfalfa mosaic virus in the walls of infected tobacco cells. Journal of General Virology 67, 2233-2239.

GoldBACH, R. \& REzelmaN, G. (1983). Orientation of the cleavage map of the 200-kilodalton polypeptide encoded by the bottomcomponent RNA of cowpea mosaic virus. Journal of Virology 46, 614-619.

Greif, C., HeMmer, O. \& FrITSCH, C. (1988). Nucleotide sequence of tomato black ring virus RNA-1. Journal of General Virology 69, 1517-1529.

HARRIS, J. I. \& KNGHT, C. A. (1952). Action of carboxypeptidase on tobacco mosaic virus. Nature, London 170, 613.

Hewick, R. M., Hunkapiller, M. W., Hood, L. E. \& Dreyer, W. J. (1981). A gas-liquid solid phase peptide and protein sequenator. Journal of Biological Chemistry 256, 7990-7997.

JoRe, J., DE Geus, B., Jackson, R. J., Pouwels, P. H. \& ENGer-ValK, B. E. (1988). Poliovirus protein 3CD is the active protease for processing of the precursor protein $\mathrm{P} 1$ in vitro. Journal of General Virology 69, 1627-1636.

Koenig, R., Tremaine, J. H. \& ShePard, J. F. (1978). In situ degradation of the protein chain of potato virus $X$ at the $N$ - and C-termini. Journal of General Virology 38, 329-337.

Kubo, S., Harrison, B. D., Robinson, D. J. \& Mayo, M. A. (1975). Tobacco rattle virus in tobacco mesophyll protoplasts: infection and virus multiplication. Journal of General Virology 27, 293-304.

Meyer, M., Hemmer, O., Mayo, M. A. \& Fritsch, C. (1986). The nucleotide sequence of tomato black ring virus RNA-2. Journal of General Virology 67, 1257-1271.

Niesbach-Klosgen, U., Guilley, H., Jonard, G. \& Richards, K. (1990). Immuno-detection in vivo of beet necrotic yellow vein virusencoded protein. Virology 178, 52-61.

Randles, J. W., Harrison, B. D., Murant, A. F. \& Mayo, M. A. (1977). Packaging and biological activity of the two essential RNA species of tomato black ring virus. Journal of General Virology 36, $187-193$.

Shukla, D. D., Strike, P. M., Tracy, S. L., Gough, K. H. \& Ward, C. W. (1988). The $\mathrm{N}$ and $\mathrm{C}$ termini of the coat proteins of potyviruses are surface-located and the $\mathrm{N}$ terminus contains the major virusspecific epitopes. Journal of General Virology 69, 1497-1508.

SYMONS, R. H. (1985). Viral genome structure. In The Plant Viruses, vol. 1, pp. 57-81. Edited by R. I. B. Francki. New York \& London: Plenum Press.

Towbin, H., Staehelin, T. \& GoRdon, J. (1979). Electrophoretic transfer of proteins from polyacrylamide gels to nitrocellulose sheets: procedure and some applications. Proceedings of the National Academy of Sciences, U.S.A. 76, 4350-4354.

Wellink, J. \& van Kammen, A. (1988). Proteases involved in the processing of viral polyproteins. Archives of Virology 98, 1-26.

WellinK, J. \& VAN Kammen, A. (1989). Cell-to-cell transport of cowpea mosaic virus requires both the $58 \mathrm{~K} / 48 \mathrm{~K}$ proteins and the capsid proteins. Journal of General Virology 70, 2279-2286.

YPMa-Wong, M. F., Dewalt, P. G., Johnson, V. H., LaMB, J. G. \& SemLeR, B. L. (1988). Protein 3CD is the major poliovirus proteinase responsible for cleavage of the P1 capsid precursor. Virology 166, 265-270.

(Received 13 January 1992; Accepted 16 March 1992) 